\title{
PCR 法による食肉・肉製品の肉種鑑別
}

\author{
費 莎・岡山高秀* ·山之上 稔*·西川 勲* \\ 万年英之 $*$ 过 荘一* \\ 神戸大学大学院自然科学研究科, 神戸市灘区 657 \\ *神戸大学農学部，神戸市灘区 657
}

(1996. 6. 21 受付)

\begin{abstract}
要 約 PCR 法による肉種鑑別を行う目的で，既知のウシ，ブタ、ニワトリのミトコンドリア D-loop 近傍の塩基配列の相同性を調査し，それらの3種を対象に 3 七ットのプライマーBF と BR, PF (BF と同一のもの) と $\mathrm{PR}, \mathrm{CF}$ と $\mathrm{CR}$ 合成した，3種食肉と各種肉製品加ら抽出したDNAを籍型と し， $94^{\circ} \mathrm{C}-2$ 分間， 66-68 $8^{\circ} \mathrm{C}-2$ 分問， $72^{\circ} \mathrm{C}-3$ 分間で 35 回の繰り返し反応で $\mathrm{PCR}$ 増幅を行った。増幅され たDNA は2\%アガロースゲル電気泳動を用いて分析した，その結果，設計通りにウシ，ブタ、ニワトリ に特異的な DN $\Lambda$ 断片（518，321，400bp）が増幅された．この方法を生肉，加熱肉及びいくつかの肉製 品について適用したところ，試料に含まれていると推定される種特異的な DNA 断片が検出された。 さ らに, ウシ,ブタ,ニワトリの3セットプライマーを混合することで, 3 種類の食肉の存在を一度の分析 で鑑定できた，羊肉を牛肉之誤認する可能性は否定された，混合 DNA を用いてウシ，ブタ、ニワトリの 複数種の DNA の検出限度について検討した結果, 混合サンプル中のそれぞれの検出限界は $0.1 \%$, $0.001 \% ， 1 \%$ で，いずれの場合です肉製品への他種肉の混合度合を知るに十分な感度を有していた。
\end{abstract}

日畜会報， 67 (10)：900-905，1996

食肉，肉製品の肉種鑑別法はDNA の分析技術の発展 に伴い急速に進歩している.1983 年に新しく開発された PCR (Polymerase Chain Reaction) 法 ${ }^{10)}$ は特定の DNA 断片をインビトロで，短時間に大量に增やすこと ができる技術である。この技術を肉種鑑別法に応用する ことでこれまでのDNAハイブリダイゼーション法2) や, RFLP (Restriction Fragment Length Polymorphism）法4に比べて簡便かつ短時間に肉種鑑別ができ る可能性が高い。

今日，PCR 法の用途は広範に亘っており，性判別に用 いる ${ }^{8)}$ ，遗伝病の診断に用いる ${ }^{6)}$ などの実用例む多く なっている.一方，対象をミトコンドリアに限って見れ ば，その塩基配列を比較することで系統発生学的研究に 応用している例が增加している，たとえば，Kocher ら9) は哺乳類, カエル，八エのミトコンドリアDNA (mtDNA) の塩基配列を比較して保存性の高い領域老選 び出し，その領域にプライマーを設定することにより，

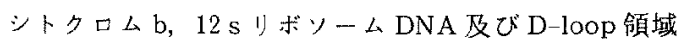
が広籍囲の動物種で增幅でき, 系統発生学的研究に利用
出来ることを示睃した。 また，千国ら文，Chikuni ら mtDNAのシトクロムb遗伝子の塩基配列の違いをも とに，PCR-RFLP 法を用いて肉種鑑別が可能で，近緑 種であるヒッジとヤギの肉種鑑別すできることを示し た。 以上の上うな PCR 法の特性を考元ると，工夫次第 で值接的かつ迅速・簡便な肉種鑑別法の開発が可能亡考 えられる。

そこで，本実験では PCR 法に上るより迅速かつ簡便 な食肉, 肉製品の肉種鑑別法を見出すことを目的とし, 食肉産業で最も多く使用されている豚肉, 鵎肉, 牛肉及 びその肉製品, 特に加熱加工された肉製品を分析の対象 として，PCR 法の有効性を检討した，PCR 法による内 種鑑別を進死で, mtDNAのD-loop 領域に的をし ぼり，ウシ，ブタ，ニワトリの塩基配列の相同性を調查 した. 次いで,を扎ら 3 種に各々のプライマーを設䛠し， 各畜種毎に特異な長さの産物ができるように工大した. そして, PCR 法による增幅の条件を種々調查し, 制限醉 素を使わず，PCR 産物の分析のみで簡単に実施できる 肉穤鑑別法について検討を行った。 


\section{材料および方法}

\section{1. 実験材料}

使用した試料はすべて市販品である。肉製品は市販の ウインナーソーセージのシャウエッセン（豚肉；二ッポ ンハム(株)), バイェルン(豚肉, 牛肉; 伊藤八ム(株)), パルキー（豚肉, 鵄肉; 伊藤八ム(株)），とチルドハン バーグ (鶏肉, 豚肉, 牛肉; 伊藤八ム $($ 柇)), ミートボー ル(哭鳥肉; プリマハム(株))である。また, ウシ,ブタ, ニワトリの生肉試料は市販の晩肉や腿肉などを材料とし た. 羊肉は市販のチルドラム（ニュージーランド産）を 用いた。

\section{2. 実験方法}

(1) DNA の調製

細切した約 $50 \mathrm{mg}$ の肉試料に $1 \mathrm{ml}$ の溶解液 ${ }^{2)}[1 \%$ SDSを含孔 $100 \mathrm{mM} \mathrm{NaCl}, 5 \mathrm{mM}$ EDTA, $100 \mathrm{mM}$ Tris-HCl buffer ( $\mathrm{pH} 9.0), 10$ mM DTT] t加えて稳や 加に振蕩し， $60^{\circ} \mathrm{C}$ で 1 時間，加温处理した後，フェノ一 ル・クロロホルム抽出, エ夕ノール沈殿を行い, DNA を得た。精製 DNA を超純水に溶解後，分光光度計で $280 \mathrm{~nm}$ と $260 \mathrm{~nm}$ の紫外部吸収を測定した。

(2) PCR 反心に用いるプライマーの合成

種特異性が高く，ウシ，ブタ，ニワトリともに塩基配 列が判明している! 5.7) ミトコンドリア D-loop 領域を選 び, PCR プライマーを設計・合成した．複数ブライマー の混合によるPCR 反応も考虑に入れて，使用するプラ イマーの数を城らすために，ウシとブタでは相同の䇛基 配列を有する個所を選択し，ウシプライマーBF とブタ プライマーPF とを同じ塩基配列とした，3種の動物の プライマーの塩基配列を表 1 に示した，設計したウシ， ブタ、ニワトリの3 種 PCR 産物の大きはそれぞれ $518 \mathrm{bp}, 321 \mathrm{bp}, 400 \mathrm{bp}$ である。

(3) PCR 法に上る DNA 增幅の条件

PCR は $20 \mu l$ の反庆液で行い, dNTP各 $25 \mu$ mole，プ ライマー各20 pmole, TaqDNA ポリメラーゼ

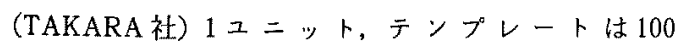

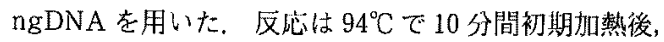
$94^{\circ} \mathrm{C}$ で 2 分間，66-68 $\mathrm{C}$ で 2 分間， $72^{\circ} \mathrm{C}$ で 3 分間を一回 の反灾サイクルとして，これを 33 回行い，最後に $72^{\circ} \mathrm{C}$ で 10 分間伸長反応老行った。 反応終了後, PCR 産物老 2\%のアガロースゲルを用いて電気泳動し，增幅した DNA断片を確認した、UVトランスイルミネーター上 で泳動像を钼察しポラロイド写真により記録した。

\section{結果}

本奏験で合成したウシブタニワトリのブライマー のアニーリングの設定温度（Tm）を表1に示した。 ウ シブタ,ニワトリの肉種鑑別をするために，䅜特異的 な DNA 断片のみが出現する 3 種食肉のアニーリングの 検出温度を見出す目的で, $60^{\circ} \mathrm{C}$ から $70^{\circ} \mathrm{C}$ ま各 $2^{\circ} \mathrm{C} の$ 間隔で奏験を行った。

市敗の牛肉，豚肉，默鳥及びその肉製品之羊肉とを材 料として，ウシ，ブタ、ニワトリの3セットプライマー について PCR 増幅条件をそれぞれ检討した。

1. ウシのプライマー在用いた PCR 条件の検討

表 1 に示したようにウシのプライマーのアニーリング の設定温度 (Tm) は $\mathrm{BF}$ が $66^{\circ} \mathrm{C}, \mathrm{BR}$ が $60^{\circ} \mathrm{C}$ である。ま ず BR の設定温度 $60^{\circ} \mathrm{C}$ で実験を始めた. しかし, $60^{\circ} \mathrm{C} て ゙$ はウシの特異的な PCR 産物だけでなく、ブタ、ニワト リの非特異的な PCR 産物む出現した。そこで設定温度

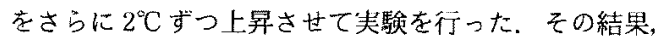
$66^{\circ} \mathrm{C}$ まで上昇させればブタ,ニワトリの非特異的な PCR 産物は完全に消失した，他方， $66^{\circ} \mathrm{C}$ を超え万条件下 ではシシの特異的な PCR 産物も消失した．したがって， このウシのプライマーでの肉種鑑別におけるアニーリン グの温度を $66^{\circ} \mathrm{C}$ とた。

図 1 は以下の材料加ら調製したDNA を铸型として, $66^{\circ} \mathrm{C}$ のテニーリング温度で, D-loop 領域の増幅をした 結果である。(B1) 列，(B3) 列之（1）列はそれぞれ生 武料のウシの腿肉, ウシの肝炡, ウシとブタの混合肉, (B2) 列之 (4) 列は $100^{\circ} \mathrm{C}$ で 30 分間加熱した牛腿肉, 及 びウシブタニワトリの泿合肉，また（2）列と（3）

Table 1. Primer sequences and annealing temperature for PCR amplification

\begin{tabular}{l|l|c|c|c}
\hline \hline & Forward primer $\left(5^{\prime} \rightarrow 3^{\prime}\right)$ & Tm $\left({ }^{\circ} \mathrm{C}\right)$ & Reverse primer $\left(5^{\prime} \rightarrow 3^{\prime}\right)$ & Tm $\left({ }^{\circ} \mathrm{C}\right)$ \\
\hline Cattle & GGATCCCTCTTCTCGCTCCG $(\mathrm{BF})$ & 66 & GGTTAAGCTACATCAACGGG $(\mathrm{BR})$ & 60 \\
\hline Pig & The same primer as BF $(\mathrm{PF})$ & 66 & ACTGAATAGCACCTTGTTTGG(PR) & 60 \\
\hline Chicken & CCCCTTTCCCCAGGGGGGGT $(\mathrm{CF})$ & 70 & AGGGGTTGCTGATCTCTCGT (CR) & 62 \\
\hline
\end{tabular}

$\mathrm{Tm}$ (Melting temperature) $=\mathrm{G} \cdot \mathrm{C} \times 4+\mathrm{A} \cdot \mathrm{T} \times 2$. 
費・岡山・山之上・西川・万年・辻

列は加熱肉製品のハンバーグとウインナーソーセージで ある. 図1に示したように, ウシを含む生肉, 加熱肉あ るいは加熱肉製品とも設計通りの $518 \mathrm{bp}$ の特異的な DNA 断片が增幅された：この同じ条件の下ではブタ (P), ニワトリ (C) は增幅されなかった. さらに, ウシ と比較的近縁関係にあるヒッジ（L）であ增幅は見られ なかった。

2. ブタのプライマーを用いた PCR 条件の検討

ブタであウシと同じように $60^{\circ} \mathrm{C}$ から $70^{\circ} \mathrm{C}$ までの最適 アニーリング温度を設定する実験を行った，その結果， ブタのプライマー (BF, PR)のアニーリング温度もウシ 之同様 $66^{\circ} \mathrm{C}$ に決定した. $66^{\circ} \mathrm{C}$ のアニーリング温度で分 析した結果を図 2 に示した. ブタを含む試料はいずれあ 設計通りの $321 \mathrm{bp}$ の特異な DNA 断片が増幅された. ブ 夕のプライマーを用いたこの条件ではウシ (B), ニワト リ (C), ヒッジ (L) ともに增幅されなかった.

3. ニワトリのプライマーを用いた PCR 条件の検討 ニワトリのプライマー（CF, CR）についてアニーリ ングは $62^{\circ} \mathrm{C}$ から $70^{\circ} \mathrm{C}$ までの温度設定で実験を行った。 その結果, アニーリング温度を $68^{\circ} \mathrm{C}$ に決定した. $68^{\circ} \mathrm{C}$ のアニーリング温度で分析した結果を図 3 に示した. ワトリを含む試料ではいずれあ設計通りの $400 \mathrm{bp}$ 特異 的な DNA 断片が堌幅された。このプライマーセットで は, ウシ (B), ブタ (P), ヒッジ (L) での DNA 断片の

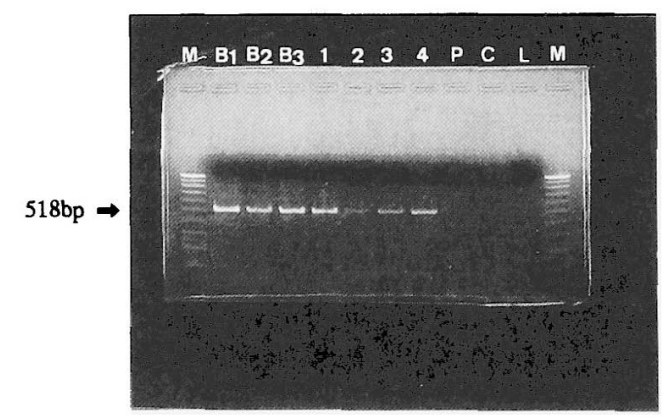

Fig. 1. PCR products using bovine primers from fresh and cooked beef, pork, chicken and lamb.

(B 1). raw beef, (B 2). beef heated at $100^{\circ} \mathrm{C}$ for 30 min, (B3). bovine liver, (1). beef and pork mixed (1:1), (2). hamburg containing chicken, pork and beef, (3). Vienna sausage containing pork and beef, (4). beef, pork and chicken are mixed $(1: 1$ : 1) and then heated at $100^{\circ} \mathrm{C}$ for $30 \mathrm{~min}$, (P). raw pork, (C). raw chicken, (L). raw lamb.

$\mathrm{M}$ is molecular marker; superladder low $100 \mathrm{bp}$ ladder.
增幅は認められなかった。

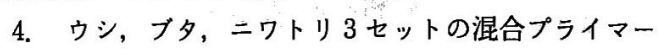
を用いた PCR 条件の検討

本肉種鑑別法の簡便化を計るために, ウシ (BF,

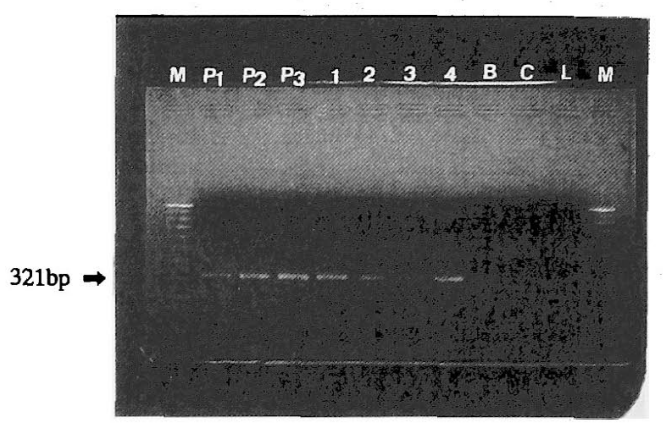

Fig. 2. PCR products using pig primers from fresh and cooked beef, pork, chicken and lamb. (P 1). raw pork, (P 2). pork heated at $100^{\circ} \mathrm{C}$ for 30 min, (P 3). pig liver, (1). pork sausage, (2). Vienna sausage containing pork and beef, (3). hamburg containing chicken, pork and beef, (4). beef, pork and chicken are mixed $(1: 1: 1)$ and then heated at $100^{\circ} \mathrm{C}$ for $30 \mathrm{~min},(\mathrm{~B})$. raw beef, (C). raw chicken, (L). raw lamb.

$\mathrm{M}$ is molecular marker; superladder low $100 \mathrm{bp}$ ladder.

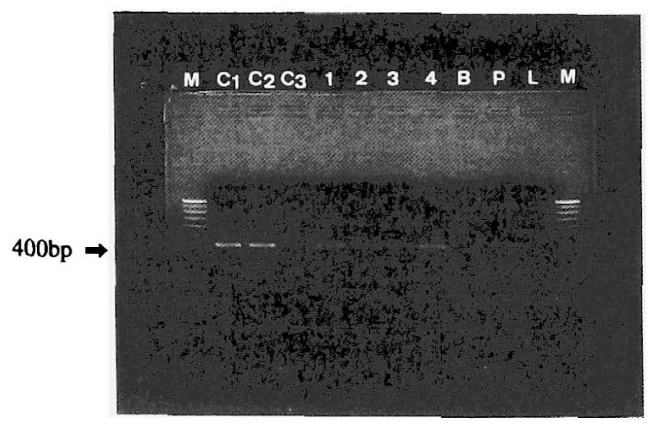

Fig. 3. PCR products using chicken primers from fresh and cooked beef, pork, chicken and lamb.

(C 1). raw chicken, (C 2). chicken heated at $100^{\circ} \mathrm{C}$ for $30 \mathrm{~min}$, (C 3 ). chicken liver, (1). meat ball of chicken, (2). Vienna sausage containing pork and chicken, (3). hamburg containing chicken, pork and beef, (4). beef, pork and chicken are mixed $(1: 1: 1)$ and then heated at $100^{\circ} \mathrm{C}$ for $30 \mathrm{~min}$, (B). raw beef, (P). raw pork, (L). raw lamb.

$\mathrm{M}$ is molecular marker; superladder low $100 \mathrm{bp}$ ladder. 


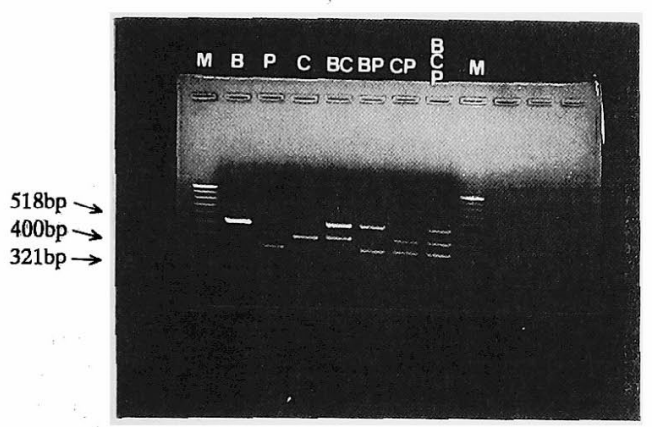

Fig. 4. PCR products amplified using three sets of primers from different types of fresh meats.

(B). beef, (P). pork, (C). chicken, (BC). beef and chicken, (BP). beef and pork, (CP). chicken and pork, (BCP). beef, chicken and pork.

$\mathrm{M}$ is molecular marker; superladder low $100 \mathrm{bp}$ ladder.

$\mathrm{BR})$, ブタ ( $\mathrm{BF}, \mathrm{PR})$, ニワトリ $(\mathrm{CF}, \mathrm{CR}) 3$ セットの プライマーを同時に用いて, 一度に 3 種の食肉を鑑別出 来るか否かを検討した. アニーリングの温度は $66^{\circ} \mathrm{C}$ と した.

その結果は図 4 に示したように, (B) 列の牛肉, (P) 列の豚肉, (C) 列の鶏肉, そして, (BC) 列の牛肉と鶏 肉, (BP) 列の牛肉之豚肉, (CP) 列の彩肉之豚肉, 及び (BCP) 列の牛肉, 鷄肉と豚肉より精製した DN $\Lambda$ を用い て，3セットのプライマーを混合した場合においても， 用いた DNA に対応する種特異的な DNA 断片のみが検 出された。このことから一度の分析で， 3 種の肉種鑑別 が可能であることが示された.

5. 混合肉製品における牛肉, 豚肉, 鶏肉の検出限界 についての検討

複数の種の肉が混合されている場合を想定して，それ ぞれの混合割合が検出出来る限界について検討した．図 5 はブタの DNA $500 \mathrm{ng}$ と一定とし， ウシの DNA 量 を $50,10,5,1 ， 0.5,0.1,0.05 \mathrm{ng}$ の段階で変化させた. プライマーはウシ（BF， BR）のものを用いた時の結果 を示したあのである.この結果，ウシの DNA が $0.5 \mathrm{ng}$ まで検出が可能であることが判明した，すなわち，ブタ の DNA 中でのウシの DNA 含有量の検出限度は $0.1 \%$ であった。これは豚肉 $1 \mathrm{~kg}$ に対し, 牛肉 $1 \mathrm{~g}$ が混合して いる場合に相当し，実用に耐え得る検出感度と言える.

同様に，それぞれのプライマーを用いて，ブタの DNA の検出限度は $0.001 \%$ で, ニワトリの DNA の検出 限度は $1 \%$ であった。

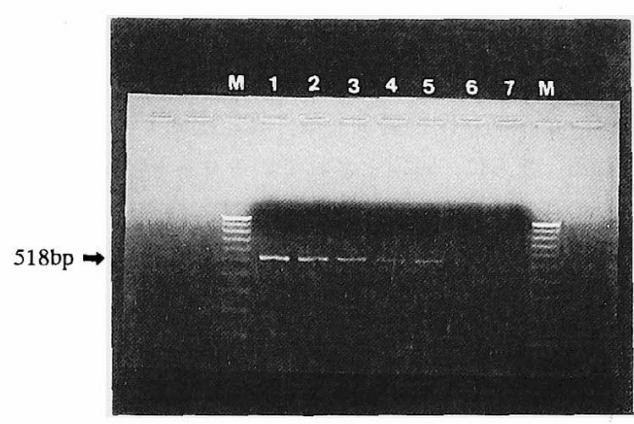

Fig. 5. PCR products amplified using bovine primers from porcine DNA samples containing serially diluted bovine DNA.

$500 \mathrm{ng}$ of porcine DNA were mixed with serially diluted bovine DNA of $50,10,5,1,0.5,0.1,0.05 \mathrm{ng}$ respectively shown in lanes $1,2,3,4,5,6$ and 7 . $\mathrm{M}$ is molecular marker; superladder low $100 \mathrm{bp}$ ladder.

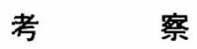

PCR 法によるウシ, ブタ,ニワトリ 3 種類の食肉, 肉 製品の肉種鑑別が可能で，羊肉を牛肉と誤認する可能性 あ否定された. しかも，制限酵素を使わず，一度の分析 で， 3 種の肉種鑑別ができる万法は今まで発表されてい るいずれの方法 ${ }^{3,4}$ より簡便かつ短時間で実施できる肉 種鑑別法である.

効率の良い特異的なプライマーを選択する方法は経験 的なものであり，亡゙のようなプライマーが効率的である かを知る法則性はない，また，プライマーを混合して複 数の個所の増幅を試みる場合はプライマー数に比例して プライマー間のアニーリングによるプライマー・ダィ マーの形成される恐れがあって，この回避も経験的なも のである. 本研究で合成したプライマーを用いて, ウシ, ブタ, ニワトリの複数種の検出限度について検討した結 果はそれぞれ $0.1 \%, 0.001 \% ， 1 \%$ であった.この検出限 度の違いは，プライマーの効率と関係があると考えられ る.しかし, 検出限度の一番低い二ワトリ(1\%)の場合 でむ $500 \mathrm{ng}$ ブタの DNA 中に $5 \mathrm{ng} ニ$ ニリの DNA が 存在すれば検出できた。これは例えば，豚肉 $1 \mathrm{~kg}$ に対 し, 鶏肉 $10 \mathrm{~g}$ が混合している場合に相当する。したがっ て,このレベルでも実用的には十分な検出感度と思われ る.

本法のもう一つの特徴は, DNA 粗調製物や加鄎変性 したサンプル由来の鋳型 DNA からであ目的の塩基配列 が増幅できることである. PCR 法による食肉, 肉製品の 


$$
\text { 嘖·岡山、山之上·西川・万年 - 辻 }
$$

肉種鑑別は従来の方法, ${ }^{2,31}$ に比べて確実かつ容易で，実 用的である．今回の肉棰鑑別の検討はあくまで定性的で あるが，定量的な肉種鑑別委条件設定次第では可能と考 兑ら机る。ささに，食用上されているマトン，家兔，馬， 魚などの種特異的なプライマーの設計，合成により，本 法を基璴上する多くの原料肉の肉種鑑別法への屡開の可 能性が示された。 また，DNA 抽出法をより簡便にする ことで，さらに迅速な肉種鑑别ができると考えられる．

\section{文献}

1) Anderson $S$, Bruijn MHLde, Coulson AR, Eperon IC, Sanger F, Young IG. Complete sequence of bovine mitochondrial DNA conserved features of the mammalian mitochondrial genome. J. Mol. Biol., 156 : 683717. 1982.

2) Chikuni $K$, Ozutsumi K, Koisikawa T, Kato $S$. Species identification of cooked meats by DNA hybridization assay. Meat Sci., $27: 119-128$. 1990.

3) Chikuni K, Tabata T, Kosugiyama M, Monma $M$, Saito $M$. Polymerase chain reaction assay for detection of sheep and goat meats. Meat Sci., $37: 337-345.1994$.

4）千国幸一・田畑利幸・崈滕昌義・門間美千子。 トクロム b 遗伝子の塩基配列の違いによる肉種
鑑別。日畜会報，65：571-579. 1994.

5) Desjardins $P$, Morais R. Sequence and gene organization of the chicken mitochondrial genome. J. Mol. Biol., 212 : 599-634. 1990.

6）藤井順逻．ブタ HAL 倦伝子の検出：骨格筋リア ノジンセプター遺伝子 (RYR1) 点突然变異。動 物遗伝研究会誌，21：56-61. 1993 。

7) Ghivizzani SC, Mackay SLD, Madsen CS, Laipis PJ, Hauswirth WW. Transcribed heteroplasmic repeated sequences in the porcine mitochondrial DNA D-loop region. J .Mol. Evol., 37 : 36-47. 1993.

8）陰山聡一・箖安 㥉・日烟利幸・千国幸一，家音 の性決定遗伝子（SRY）保存領域の PCR 法に上 る增幅と塩基配列の種差。日畜会報，63：10591065. 1992.

9) Kocher TD, Thomas WK, Meyer A, Edwards SV, Paabo S, Villablanca FX, Wilson AC. Dy. namics of mitochondrial DNA evolution in animals : Amplification and sequencing with conserved primers. Proc. Natl. Acad. Sci. USA, 86 : 6196-6200. 1989.

10) Saiki RK, Gelfand DH, Stoffel S, Scharf SJ, Higuchi R, Horn GT, Mullis KB, Erlich HA. Primer-directed enzymatic amplification of DNA with a thermostable DNA polymerase. Science, 239 : 487-491. 1988. 


\title{
Species Identification of Meats and Meat Products by PCR
}

\author{
Sha FEI, Takahide OKAYAMA*, Minoru YAMANOUE*, \\ Isao NISHIKAWA*, Hideyuki MANNEN* \\ and Soichi TSUJI* \\ Graduate School of Science and Technology, Kobe University, \\ Nada-ku, Kobe-shi 657 \\ * Faculty of Agriculture, Kobe University, \\ Nada-ku, Kobe-shi 657
}

Polymerase Chain Reaction (PCR) was applied to species identification of meats and meat products. For the identification of meat species by PCR, three sets of primer, i.e., BF $\left(5^{\prime}\right.$ GGATCCCTCTTCTCGCTCCG-3') and BR (5'-GGTTAAGCTACATCAACGGG $\left.3^{\prime}\right)$ for cattle, PF (BF) and PR (5'-ACTGAATAGCACCTTGTTTGG-3') for pig, and also CF $\left(5^{\prime}\right.$-CCCCTTTCCCCAGGGGGGGT-3') and CR (5'-AGGGGTTGCTGATCTCTCGT-3') for chicken, were designed according to the published mitochondrial D-loop DNA sequences from cattle, pig and chicken. Amplification was carried out 35 cycles of denaturation at $94^{\circ} \mathrm{C}$ for $2 \mathrm{~min}$, annealing at $66-68^{\circ} \mathrm{C}$ for $2 \mathrm{~min}$, and extension at $72^{\circ} \mathrm{C}$ for $3 \mathrm{~min}$ in the presence of Taq DNA polymerase. Products amplified were analyzed by $2 \%$ agarose gel electrophoresis. Products amplified from beef, pork and chicken gave single specific DNA fragment of $518 \mathrm{bp}, 321 \mathrm{bp}$ and $400 \mathrm{bp}$, respectively. Using this method, several meat products were analyzed. Mixing of beef, pork or chicken in meat products was revealed by identification of each single specific DNA fragment. When three sets of primers were employed together, beef, pork and/or chicken specific DNA fragment from these mixed meat products could be identified by only one PCR reaction. Sheep is closely related species of cattle, but lamb does not gave any amplyfied DNA fragment under these experimental conditions. The detection limits in a mixed DNA sample were approximately $0.1 \%$ beef in pork, $0.001 \%$ pork in beef, $1 \%$ chicken in pork, respectively.

Anim. Sci. Technol. (Jpn.) 67 (10): 900-905, 1996

Key words : PCR, Species identification, Meat, Meat products 